Discussion Papers in Economics and Econometrics

\begin{tabular}{||l||}
\hline SKILLED EMIGRATION, BUSINESS \\
NETWORKS AND FOREIGN DIRECT \\
INVESTMENT \\
Maurice Kugler \\
Hillel Rapoport \\
No. 0503 \\
\hline
\end{tabular}

This paper is available on our website http://www.socsci.soton.ac.uk/economics/Research/Discussion_Papers 


\title{
Skilled Emigration, Business Networks and Foreign Direct Investment*
}

\author{
Maurice Kugler and Hillel Rapoport ${ }^{\dagger}$ \\ March 2005
}

\begin{abstract}
A bstract
In a global context foreign direct investment (FDI) and migration substitute one another in the matching process between workers and firms. However, as labor flows can lead to the formation of business networks, migration can actually facilitate FDI in the long-run. We first present a stylized model for a small open economy illustrating these offsetting effects. We then use U.S. data on bilateral labor inflows and capital outflows to measure the extent of contemporaneous substitutability and dynamic complementarity between migration and FDI. We find that brain drain and FDI inflows are negatively correlated contemporaneously but that skilled migration is associated with future increases in FDI inflows. We also find suggestive evidence of substitutability between current migration and FDI for migrants with secondary education, and of complementarity between past migration and FDI for unskilled migrants.
\end{abstract}

Keywords: Brain drain, foreign direct investment inflows, migrant ties and business networks

J EL Codes: F22, F43, O41

${ }^{*}$ We thank Frederic Docquier, Edward Taylor and John Whalley for comments and suggestions and the hospitality of the Stanford Center for International Development, where both authors were visitors when this research was initiated.

${ }^{\dagger}$ Maurice Kugler. University of Southampton. e-mail: mdk1@soton.ac.uk. Hillel Rapoport. Bar-Ilan University. e-mail: hillel@biu.ac.il 


\section{Introduction}

The last few decades have seen a tremendous increase in the international movements of factors and goods, with international trade and factor flows growing much more rapidly than output. Grossly, the growth rate of international trade has been twice that of world output between 1990 and 2000; even more remarkable is the growth of global FDI flows, which has been triple the growth rate of international trade flows over the period. While such growth has been faster in some regions than others, it has not been localized in just one or two regions, as shown in Figure 1. Global figures for international migration are less easy to obtain because of poor data quality and lack of international harmonization in the definition of a migrant (Zlotny, 1998). International migration is clearly on the rise, however, as reflected for example by the fact that the total number of foreign-born individuals residing in OECD countries (i.e., the OECD immigration stock) has increased by $50 \%$ over the same period. The latter figure is amazing because in contrast to the liberalization trend that has characterized trade and FDI, restrictive immigration policies have instead been introduced by most receiving countries with the double objective of decreasing the quantity and increasing the quality of immigration (Faini, 2004). Only the second of these objectives has been achieved; indeed, the number of highly-skilled immigrants (foreign-born individuals with tertiary education) living in an OECD member country has increased by $70 \%$ between 1990 and 2000, but the number of low-skill migrants has risen too, although at a lower pace (28\%) (Docquier and Marfouk, 2004), as displayed in Figure 2.

This paper investigates whether migration and foreign direct investments (FDI) are substitutes, as standard trade models would predict (either jobs flow to workers or workers to jobs) or complements, as recent socio-economic literature on the role of diasporas in favoring capital inflows and technology diffusion to the migrants' origin countries would seem to suggest. In a standard trade-theoretic framework, the relationship between migration and trade as well as between migration and FDI is a relationship of substitutability. Indeed, trade contributes to factor price equalization and therefore lowers incentives for factor mobility; at the same time, factor movements (beyond the Rybszinski cone) reduce price differentials and, hence, the scope for trade. Similarly, capital is expected to flow to where the type of labor used intensively in production is abundant and, other things equal, workers will supply their labor services where the highest salary can be obtained. Through such 
mechanisms, migration and FDIs are substitute ways to match workers and employers located in different countries. On the other hand, there is a growing literature emphasizing that migrant networks facilitate bilateral economic transactions through their removing of informational and cultural barriers between host and origin countries. Such a diaspora externality has long been recognized in the sociological literature and, more recently, by economists in the field of international trade. In many instances indeed, and, as explained, in contrast to the predictions of standard trade models, trade and migration appear as complements (e.g., Gould, 1994). Interestingly, such a complementarity has been shown to prevail mostly for trade in heterogeneous goods, where ethnic networks help overcoming information problems linked to the very nature of the goods exchanged (Rauch and Casella, 2003, Rauch and Trindade, 2002).

In a similar spirit, migration may also facilitate the formation of the types of business links which lead to FDI project deployment in a particular location. Hence, while emigration of workers into a country may mitigate to some extent the incentives for FDI from the host to the origin country of migrants, their sheer presence in the host country can be a catalyst to establish the required links to achieve efficient distribution, procurement, transportation and satisfaction of regulations. An important barrier to a multinational corporation's viability to set up a subsidiary in a developing country can be uncertainty. To the extent that migrants integrate to the business community, a network can emerge whereby migrants liaise between potential investors and partners (both private and public) in various aspects of setting up a production facility in the country of origin of the migrant. Such mechanisms through which migration and FDI seem to complement each thanks to migrants taking part in business networks are described in various sectoral case-studies, notably in the case of the software industry (Saxeenian, 2001, Arora and Gambardella, 2004, Commander et al., 2004b). While the channel just described would seem to apply mainly to skilled migrants, there are other channels through which unskilled migrants may also contribute to relax information constraints on FDI. Indeed, their integration into the host country labor market acts as a revelator of the characteristics of the workforce in their home country and may therefore reduce uncertainty and possibly remove any concern potential investors could have in this respect. Hence, migration of both skilled and unskilled workers can facilitate in 
the long run the outflow of FDI from the destination to the origin country. ${ }^{1}$

How is the relationship of substitutability or complementarity between migration and FDI affected by the skill composition of migration and by the pattern (i.e., sectoral composition) of FDI? Surprisingly, these issues have so far been neglected in the literature. Focusing on the impact of trade liberalization on migration in a cross-section of countries, Lopez and Schiff (1998) concluded to a relationship of complementarity between trade and unskilled migration and to a relationship of substitutability between trade and skilled migration, but did not analyze the pattern of migration in relation to FDI. More recently, Aroca and Maloney (2002) analyzed the impact of FDI on US-Mexico migration and concluded to a relationship of contemporaneous substitutability between the two; however, they did not consider possible dynamic relationships between the two, nor did they consider the possible impact of migration on FDI. Finally, recent studies suggest that there are FDI spillovers on upstream industries in developing countries (e.g., Kugler, 2000, 2005, Smarzynska, 2004). To the extent that such spillovers induce adoption of more skill-intensive technologies, they may magnify the substitution effect between skilled migration and FDI.

On the whole, our working assumption is that the relationship between migration and FDI is characterized by the offsetting effects of contemporaneous substitutability and dynamic complementarity. In Section 2 we first present a stylized model that captures the main mechanisms through which international labor and capital movements can be linked; the aim of this simple theoretical framework is to derive a number of predictions to be tested empirically. Section 3 presents the data used for the empirical analysis; the main data sources we use are US Census data on immigration stocks in 1990 and 2000, and data from the US Bureau on Economic Analysis on FDI outflows. Section 4 discusses our empirical strategy and presents the results. These are broadly consistent with the predictions of the theoretical framework in that skilled migration (brain drain) and FDI inflows are negatively correlated contemporaneously but past skilled migration is associated with an increase in current FDI inflows. We also find suggestive evidence of substitutability between current migration and FDI for migrants with secondary

\footnotetext{
${ }^{1}$ If verified, this is another channel - alongside remittances, return migration, and the effect of migration prospects on education investment - through which skilled migration affects growth and welfare in the sending countries. See Rapoport and Docquier (2005) on the growth effects of remittances, and Domingues Dos Santos and Postel-Vinay (2003) on return migration as a source of growth.
} 
education, and of complementarity between past migration and FDI for unskilled migrants. Section 5 concludes.

\section{Theoretical framework}

Consider a small open developing economy where, at each period, a composite good is produced according to a Cobb-Douglas technology with constant returns to scale:

$$
Y_{t}=A\left(H_{t}\right) K_{t}^{1-\alpha} L_{t}^{\alpha}
$$

with $L_{t}=N_{t} H_{t}$, the stock of labor measured in efficiency units and $H_{t}$ the average number of such units (or average level of human capital) per worker. In this setting, skilled and unskilled workers are perfect substitutes and total factor productivity depends on human capital externalities, as captured by the expression of the scale factor $A$. Assuming competitive markets and denoting by $k$ the capital to labor ratio, factor returns are given by:

$$
\begin{aligned}
r_{t} & =(1-\alpha) A\left(H_{t}\right) k_{t}^{-\alpha} \\
w_{t} & =\alpha A\left(H_{t}\right) k^{1-\alpha}
\end{aligned}
$$

The economy is "open" in that capital is perfectly mobile internationally and "developing" in that, due to persistent technological gaps, the wage rate (or wage per efficient unit of labor) is higher in a more advanced economy which represents a potential destination for migrants. ${ }^{2}$ By contrast, labor is imperfectly mobile internationally due to the presence of migration costs (possibility coupled to liquidity constraints that prevent profitable migration investments) and to the fact that destination countries restrict immigration both quantitatively and qualitatively (i.e., selective immigration policy). Wage-differentials, migration costs and immigration policy determine the pattern of migration (i.e., whether there is self-selection or out-selection and whether migrants have more or less than average skills).

International capital flows are such that the domestic interest rate is equal to the international interest rate augmented by a country-risk premium $\pi$ associated to internal factors such as risk, political instability, corruption, individual freedom, degree of trade liberalization, quality of governance, etc.

\footnotetext{
${ }^{2}$ The destination country is assumed to be large. That is, its domestic prices and wages are assumed to be unaffected by international factor flows to/from one single country.
} 
With $r_{t}=r^{*}+\pi_{t}$, we have, therefore:

$$
\begin{aligned}
& k_{t}=\frac{(1-\alpha) A\left(H_{t}\right)}{r^{*}+\pi_{t}} \equiv k\left(\pi_{t}, H_{t}\right) \\
& w_{t}=\alpha{\frac{1-\alpha}{r^{*}+\pi_{t}}}^{\frac{1-\alpha}{\alpha}}\left[A\left(H_{t}\right)\right]^{\frac{1}{\alpha}} \equiv w\left(\pi_{t}, H_{t}\right)
\end{aligned}
$$

with the derivatives $k_{1}^{\prime}<0, k_{2}^{\prime}>0$ and $w_{1}^{\prime}<0, w_{2}^{\prime}>0$.

The equilibrium stock of capital in the economy is thus given by:

$$
K_{t}=k_{t} L_{t}={\frac{(1-\alpha) A\left(H_{t}\right) N_{t}^{\alpha} H_{t}^{\alpha}}{r^{*}+\pi_{t}}}^{\#_{1}}
$$

The latter expression allows us to envision the causal relationships between migration and FDI that are the focus of our empirical analysis and to design our empirical strategy accordingly.

The first, immediate effect of migration is to reduce the number of workers (denoting by $m$ the migration rate, it becomes $N_{t}(1-m)$ ); any migration outflow would decrease the domestic return to capital and therefore generate a compensating outflow of capital; clearly, FDI and migration are here substitutes as more migration leads to less FDI and conversely.

Second, the skill composition of migration is also of importance. As is well known and documented, a skilled labor force is a key determinant of FDI inflows as it contributes to the capacity of the home economy to adopt new technologies, an effect often referred to as the technological externality arising from human capital formation. ${ }^{3}$ All else equal, a more skilled emigration lowers the proportion of skilled in the home population and, therefore, through a decrease in $H$, should deter FDI. In terms of our notations, if the post-migration level of human capital, $H_{t}^{m}$, is lower than the pre-migration average level of human capital, $H_{t}$, this affects capital inflows negatively in two ways, through the stronger depletion of the stock of labor $L_{t}$ and through the human capital externality captured by $A\left(H_{t}\right)$.

Third, as explained in the introduction, skilled migrants tend to take part in business networks while unskilled migrants convey information on the characteristics of the home country labor force. Hence, both types of

\footnotetext{
${ }^{3}$ See for example Klenow and Rodriguez-Clare (2004) for both a theoretical framework and survey of the empirical literature on this issue.
} 
migration help overcoming informational barriers to FDI and therefore contribute to increasing the attractiveness of the country to foreign investors. We interpret this impact of emigration as a negative shock on the origin country risk premium $\left(\pi_{t} \rightarrow \pi_{t}^{m}\right)$.

Finally, one must also bear in mind that education decisions are impacted by the prospect of migration. Back in the 1970s, the first generation of brain drain models (e.g., Bhagwati and Hamada, 1974, McCullock and Yellen, 1977) did recognize this but considered that destination (Western) countries reaped all the benefits from the induced increase in the international supply of brains. It is only recently that, starting with Mountford (1997), Stark et al. (1997, 1998), Vidal (1998) and Beine et al. (2001, 2003), a growing literature has demonstrated that migration prospects can not only boost domestic enrollment in higher education but also increase net human capital formation at home. ${ }^{4}$ This suggests that the effect of a more skilled emigration on $H$ and, therefore, on FDI inflows, could be ambiguous; indeed, one would expect a detrimental brain drain to weaken the dynamic complementarity between skilled migration and FDI emphasized above, and to strengthen it instead in case of a beneficial brain drain.

Notwithstanding this last, indirect effect, the central predictions from our stylized model are that all else equal, a larger and more skilled migration network (given the additional impact of skilled migrants through their being part of business networks) should encourage future FDI while contemporaneous international factor movements should reflect a negative correlation between labor outflows and capital inflows.

\section{Data description}

The main data sources we use are US Census data on immigration stocks by country of origin and education level for 1990 and 2000, and data from the US Bureau of Economic Analysis on FDI outflows by destination country and sector (manufacturing vs. services). The stocks of migrants are classified by the highest level of schooling attained grouped as primary, secondary or tertiary education.

The estimates of US direct investment position abroad are valued at historical cost and include international transactions between US. parent com-

\footnotetext{
${ }^{4}$ See Commander et al. (2004a) and Docquier and Rapoport (2004) for analytical surveys of this literature.
} 
panies and their foreign affiliates for calendar years 1982-2001. International transactions consist of capital outflows and its components (equity capital outflows, reinvested earnings, and intercompany debt outflows); income; royalties and license fees; and charges for other services. The data for 1982, 1989, and 1994 are universe values from benchmark surveys, adjusted from the fiscal year basis on which the data were reported to a calendar year basisthe basis required for the international transactions accounts. The data for 1983-88, 1990-93 and 1995-2001 are universe estimates that are the sum of sample data reported in BEA's quarterly surveys of US. direct investment abroad plus an estimate of data for affiliates not reported in the quarterly surveys. The estimates for unreported affiliates for 1983-88 are derived both by extrapolating forward data reported for these affiliates in the 1982 benchmark survey based on the movement of the sample data in the subsequent years, and by interpolating backwards between the 1989 and 1982 benchmark surveys. The estimates for unreported affiliates for 1990-93 are derived by extrapolating forward data reported for these affiliates in the 1989 benchmark survey based on the movement of the sample data in the subsequent years. Likewise, the estimates for unreported affiliates for 1995-2001 are derived by extrapolating forward data reported for these affiliates in the 1994 benchmark survey based on the movement of the sample data in the subsequent years.

Beginning with 1994, the positions and transactions associated with intercompany debt between parents and foreign financial affiliates that are not depository institutions but are primarily engaged in financial intermediation are reclassified from the direct investment accounts to the accounts for US. nonbanking concerns' transactions with unaffiliated foreigners. Similarly, interest receipts and payments associated with these debt transactions are reclassified from the direct investment income account to the otherprivate income account. Other types of capital transactions-equity capital and reinvested earnings-with these financial intermediaries and the associated earnings receipts continue to be classified as direct investment.

On the basis of these flows, the BEA builds for each country and sector receiving FDI from the US the historical capital stock. Taking account of depreciation, this allows to compute the change in each country's sectoral capital stock that may be attributed to accumulated FDI of US origin. It is this variable over the 1990s that we use as dependent variable. Among the more than 100 countries for which immigration data is available, there were only 55 countries for which we were able to calculate the change of FDI 
financed capital formation between 1990 and 2000. We use GDP, GDP per capita, and regional dummies for Europe and Latin America as controls, and add interaction terms between regional dummies and migration variables to make allowance for regional determinants of migration and FDI patterns. Table 1 presents the list of countries.

Table 2 presents the descriptive statistics for the variables used in the empirical analysis. Number of observations per variable is 55 corresponding to the number of countries for which we can construct our historical stock variables of emigration by schooling level and sectoral capital formation financed with FDI, where the host country of the US multinational corporation subsidiaries is the country of origin of the US immigrant stocks. Let $\Delta K^{s}$ be the change between 1990 and 2000 in the log of $s$ capital stock (where henceforth $s=T O T, M A N, S E R$ stands for total, manufacturing and services respectively) financed with FDI from US,$K_{1990}^{s}$ is the log of the historical $s$ stock in 1990 of capital financed with FDI from the US, $\Delta M^{e}$ is the change in the 1990's of the log of the stock of migrants in the US with $e$ educational attainment (where henceforth $e=P R I, S E C, T E R$ for primary, secondary and tertiary respectively), and $M_{1990}^{e}$ is the log of the stock of migrants in the US in 1990 with $e$ educational attainment. Over the decade aggregate capital formation financed by FDI in our sample of countries rose on average by $117 \%$. The corresponding figures for manufacturing and services were $133 \%$ and $351 \%$. Even with this wide gap in growth between sectors by 2000 the average of capital stock, across the 55 countries in the sample, financed with FDI in services was half of that in manufacturing. The average stock of US immigrants by country with only primary education declined by $19 \%$ and with secondary education by $4 \%$. In contrast, the number of migrants with university education rose by $44 \%$ between 1990 and 2000. The initial stocks by the three categories of highest educational attainment were roughly similar in 1990. These observed trends are not particular to our sample. For example, Figure 1 shows aggregate FDI, not just originated in the US, inflows to various regions and there is a clear expansionary tendency across the board. While the growth of FDI is more pronounced in some regions, it is clearly not a localized phenomenom. At the same time, Figure 2 shows changes in the skill composition, measured by schooling attainment, of migrant stocks to different destinations in OECD countries. The increase in the share of university educated among immigrants observed in the US in 1990's also happened in the Australia, Canada and the EU, and overall in the OECD. Hence, while our constructions of capital and migrant stocks re- 
stricts our sample of countries, the temporal variation of the main variables in the resulting sample accords with what is observed globally.

\section{Empirical analysis}

We specify a regression in differences to mitigate concerns about endogeneity and simultaneity. In contrast to most empirical specifications on the determinants of FDI inflows, our dependent variable is the rate of change of the historical capital stock financed via FDI inflows rather than the levels of FDI. In standard analyses on FDI determinants with the explanatory variable expressed in levels, Tobit estimation is generally used to correct for censoring of the dependent variable. ${ }^{5}$ In our set up, truncated distributions are not an issue as growth of the capital stock is not restricted to be positive. At the same time, there is a sample selection issue as we have to exclude countries for which historical sectoral capital stocks financed are missing. To the extent that missing values may be caused by lack of FDI inflows induced by fundamentals in the potential recipient country, there may be a bias towards substitutability as weak fundamentals simultaneously increase migration and lower FDI.

As pointed out by Razin et al. (2004), lack of inflows may be induced by lumpy sunk costs associated with investing in the potential host country. If the costs do not change over time, they can be modelled as a fixed effect. We account for such unobserved heterogeneity by taking first differences. At the same time, we incorporate variation in the educational attainment of migrants, to proxy for heterogeneity in the skill composition of migration, and hence our framework has a differences-in-differences structure. We estimate the following regressions using OLS:

$$
\Delta K_{i, t}=X_{i, t-1}^{\prime} \alpha_{0}+M_{i, t-1}^{\prime} \beta_{0}+\Delta M_{i, t}^{\prime} \beta_{1}+\epsilon_{i}
$$

where $\Delta K_{i, t}$ is the change in the capital stock of country $i$ that is financed with FDI from the US between 1990 and 2000, $X_{i, t-1}$ is a vector of control variables including the lagged dependent variable, $M_{i, t-1}$ contains country $i$ 's

\footnotetext{
${ }^{5} \mathrm{~A}$ recent and notable exception is Razin, Rubinstein and Sadka (2004), where flaws with the use of Tobit estimation tehniques are highlighted. Coefficients from Tobit regressions are biased due to their failure to account for the fact that occurence of zeros in reported FDI may reflect economic fundamentals, beyond boundary problems.
} 
stock of migrants in the US by educational attainment in 1990, the elements of $\Delta M_{i, t}$ are the rates of change in the components by educational grade completed US immigrant between 1990 and 2000, and the term $\epsilon_{i}$ captures measurement error.

Using this specification we obtain the following results. Table 3 shows the impact of emigration patterns on FDI inflows. For total FDI, we obtain that unskilled migration is associated with rising future FDI. There is also some indication, although less significant, that brain drain is positively correlated with ensuing capital inflows. On the one hand, the positive association between unskilled emigration and total FDI inflows to the workers' origin country may relate to the revelation of information about high labor force quality from observations of their work by multinational investors. On the other hand, positive correlation of current total FDI inflows and past emigration of those holding university degrees is consistent with brain drain acting as a catalyst for the creation of international business networks.

For manufacturing FDI, we find that inflows have a significant positive association with past emigration of university graduates from the multinational corporation subsidiary's host country to the home country. Also, current FDI inflows from the US are negatively correlated with current emigration by workers with secondary education to the US. At the same time, for Latin American countries the evidence indicates a contemporaneous positive link between emigration to the US by those with primary and tertiary schooling attainments and FDI inflows from the US. A 10\% rise in the stock of university educated migrants in the US was associated with a rise of a quarter of a percentage point in the growth of capital in manufacturing financed with FDI to the migrants' country of origin. On the other hand, a $10 \%$ increase in emigration of workers with secondary education to the US over the 1990's is associated with a $7 \%$ lower capital formation in manufacturing financed with FDI from the US to the migrants' origin country.

Finally, with respect to FDI inflows directed to the service sector we find evidence consistent with contemporaneous substitutability and dynamic complementarity between skilled emigration to the US and FDI inflows from the US to the service sector, while no significant effect was found for the relationship between unskilled migration and FDI.A 10\% rise in the stock of university educated migrants in the US was associated with a rise of a half of a percentage point in the growth of capital in manufacturing financed with FDI to the migrants' country of origin. By contrast, a 1\% increase in emigration of workers with secondary education to the US over the 1990's is 
associated with a $3.5 \%$ lower capital formation in services financed with FDI from the US to the migrants' origin country.

\section{Concluding remarks}

Since international factor flows are jointly determined by technology deployment and endowment differentials, it is natural to study at the same time capital and labor movements between countries. Yet, one potential determinant of FDI which has rarely been studied is migration. The most obvious link is that to match workers and vacancies which are in different countries, either employees have to relocate to where jobs are or investments need to be undertaken to create jobs where potential employees are. In particular, FDI will flow to where the type of labor used intensively in production is abundant. At the same time, other things equal, workers will supply their labor services where the highest salary can be obtained. Through this mechanism FDI and migration are substitute ways to match workers and employers located in different countries.

Another effect that runs in the opposite direction is that migration might facilitate the formation of the types of business links which lead to FDI project deployment in a particular location. Hence, while emigration of workers into a country may mitigate to some extent the incentive for FDI outflow from the destination country of migrants to the origin country, the presence of migrants can be a catalyst to establish the required links to achieve efficient distribution, procurement, transportation and satisfaction of regulations. An important barrier to a multinational corporation's viability to set up a subsidiary in a developing country can be uncertainty and transaction costs. To the extent that migrants integrate to the business community, a network can emerge whereby migrants liaise between potential investors and partners (both private and public) in various aspects of setting up a production facility in the country of origin of the migrant.

Hence, migration can facilitate in the long run the outflow of FDI from the destination to the origin country. Through this mechanism FDI and migration complement each other. Whether brain drain is associated with a net increase in FDI inflows or not is an empirical matter. We use bilateral data of migration and FDI flows, as well as other control variables. Our benchmark is a differences-in-differences specification for FDI with country size measures (e.g. GDP and GDP per capita) and regional indicators as control 
variables and the skill composition and change over time of emigration as explanatory variables. We identify evidence consistent with contemporaneous substitutability among FDI and migration as well as dynamic complementarity, especially among migrants with more schooling. 


\section{References}

Arora, A. and A. Gambardella (2004): The Globalization of the Software Industry: Perspectives and Opportunities for Developed and Developing Countries; in A.B. Jaffe, J. Lerner and S. Stern, eds.: Innovation Policy and the Economy, Vol. 5, Cambridge, Ma.: The MIT Press, forthcoming.

Beine, Michel, Frédéric Docquier and Hillel Rapoport (2001): Brain Drain and Economic Growth: Theory and Evidence, Journal of Development Economics, 64, 1: 275-89.

Beine, Michel, Frédéric Docquier and Hillel Rapoport (2003): Brain Drain and LDCs' Growth: Winners and Losers, IZA Discussion Paper No 819, July.

Bhagwati, J. N. and K. Hamada (1974): The brain drain, international integration of markets for professionals and unemployment, Journal of Development Economics, 1, 1: 19-42.

Commander, Simon, Maria Kangasniemi and Alan L. Winters (2004a): The brain drain: curse or boon? A survey of the literature, in R. Badlwin and L.A. Winters, eds.: Challenges to Globalization, The University of Chicago Press, Chapter 7.

Commander, S., R. Chanda, M. Kangasmieni and A.L. Winters (2004b): Who gains from skilled migration? Evidence from the software industry, Manuscript, Center for Economic Performance, London School of Economics.

Docquier, Frédéric and Abdeslam Marfouk (2004): Measuring the international mobility of skilled workers, 1990-2000, Policy Research Working Paper No 3381, The World Bank, August.

Docquier, Frédéric and Hillel Rapoport (2004): Skilled migration: the perspective of developing countries, Policy Research Working Paper No 3382, The World Bank, August.

Domingues Dos Santos, Manon and Fabien Postel-Vinay (2003): Migration as a source of growth: the perspective of a developing country, Journal of Population Economics, 16, 1: 161-75.

Faini, Riccardo (2004): Trade liberalization in a globalizing world, IZA Discussion Paper No 1406, November.

Javorcik, Beata Smarzynska (2004): Does Foreign Direct Investment Increase the Productivity of Domestic Firms? In Search of Spillovers through Backward Linkages, American Economic Association, vol. 94(3), pages 605627.

Klenow, Peter J. and Andres Rodriguez-Clare (2004): Externalities and growth, NBER Working Paper No 11009, December. 
Kugler, Maurice (2000): The diffusion of externalities from Foreign Direct Investment: Theory ahead of measurement, Ph.D Dissertation, UC Berkeley.

Kugler, Maurice (2004): Spillovers from Foreign Direct Investments: within or between industries?, Journal of Development Economics, forthcoming.

Lopez, Ramon and Maurice Schiff (1998): Migration and the skill composition of the labour force: the impact of trade liberalization in LDCs, Canadian Journal of Economics, 31, 2: 318-36.

McCullock, R. and J.T. Yellen (1977): Factor mobility, regional development and the distribution of income, Journal of Political Economy, 85, 1: 79-96.

Mountford, Andrew (1997): Can a brain drain be good for growth in the source economy?, Journal of Development Economics, 53, 2: 287-303.

Rapoport, Hillel and Frédéric Docquier (2005): The economics of migrants' remittances, in L.-A. Gerard-Varet, S.C. Kolm and J. Mercier-Ythier, eds.: Handbook of the economics of giving, reciprocity and altruism, Amsterdam: North-Holland, forthcoming.

Rauch, James E. and Victor Trindade (2002): Ethnic chinese networks in international trade, Review of Economics and Statistics, 84, 1: 116-30.

Rauch, James E., Casella, Alessandra (2003) Overcoming informational barriers to international resource allocation: Prices and Ties, Economic Journal, 113, 484: 21-42.

Razin, Assaf, Yona Rubinstein and Efraim Sadka (2004): Which countries export FDI, and how much? Mimeo, Tel-Aviv University, March.

Saxeenian, A. (2001) Bangalore, the Silicon Valley of India?, CREDPR Working Paper No 91, Stanford University.

Stark, Oded, Christian Helmenstein and Alexia Prskawetz (1997): A brain gain with a brain drain, Economics Letters, 55: 227-34.

Stark, Oded, Christian Helmenstein and Alexia Prskawetz (1998): Human capital depletion, human capital formation, and migration: a blessing or a 'curse'?, Economics Letters, 60, 3: 363-7.

Vidal, Jean-Pierre (1998): The effect of emigration on human capital formation, Journal of Population Economics, 11, 4: 589-600.

Zlotnik, H. (1998): International migration 1965-96: An overview, Population and Development Review, 24, 3: 429-68. 
Figure 1- Regional Trends of FDI Inflous in 1990's

Billions of dollars
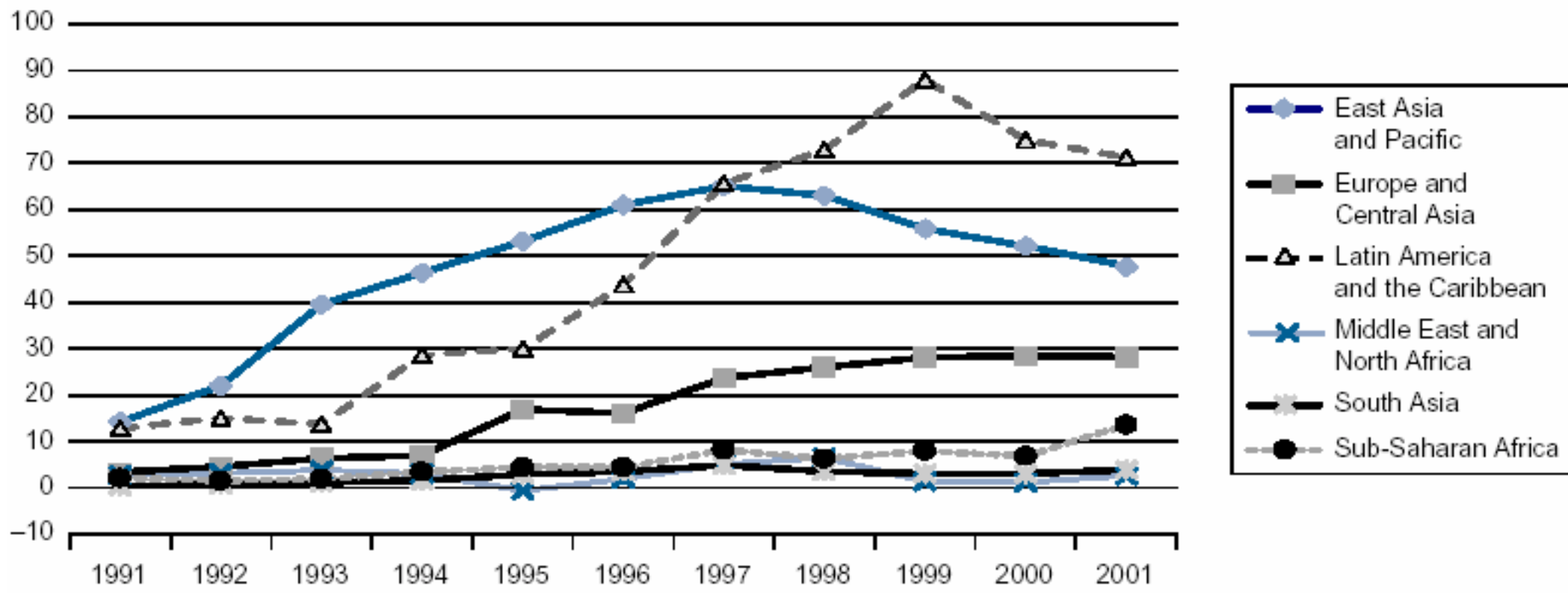
and Pacific

Source: World Bank, Global Development Finance: Country Tables and sources cited therein, various years:

World Bank staff estimates for 2001 
Figure 2- Changes in migrant composition in 1990 s

Skilled immigrants in percent of the immigration stock

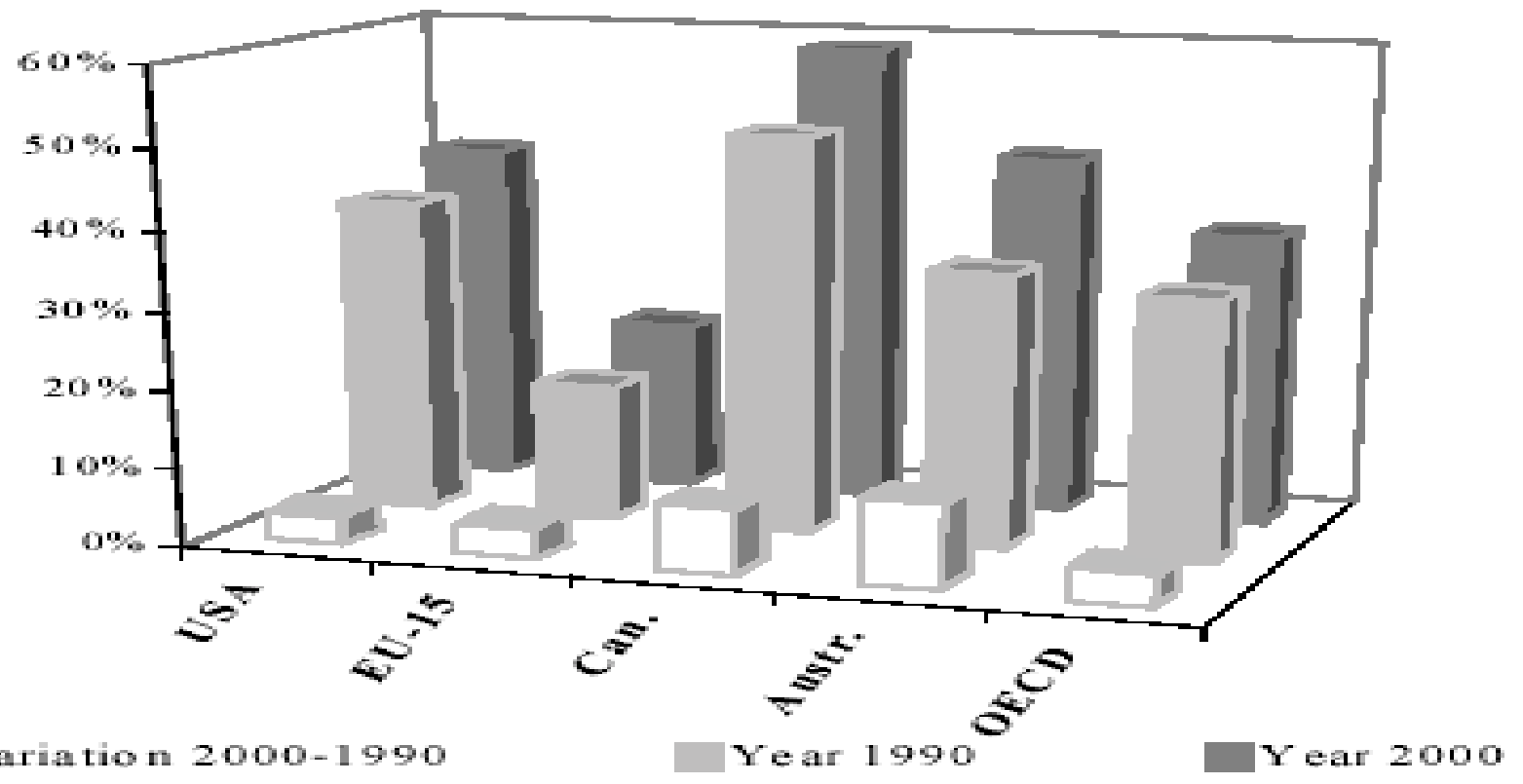

Source: Docquier and Marfouk (2004) 
Table 1 - Sample Description

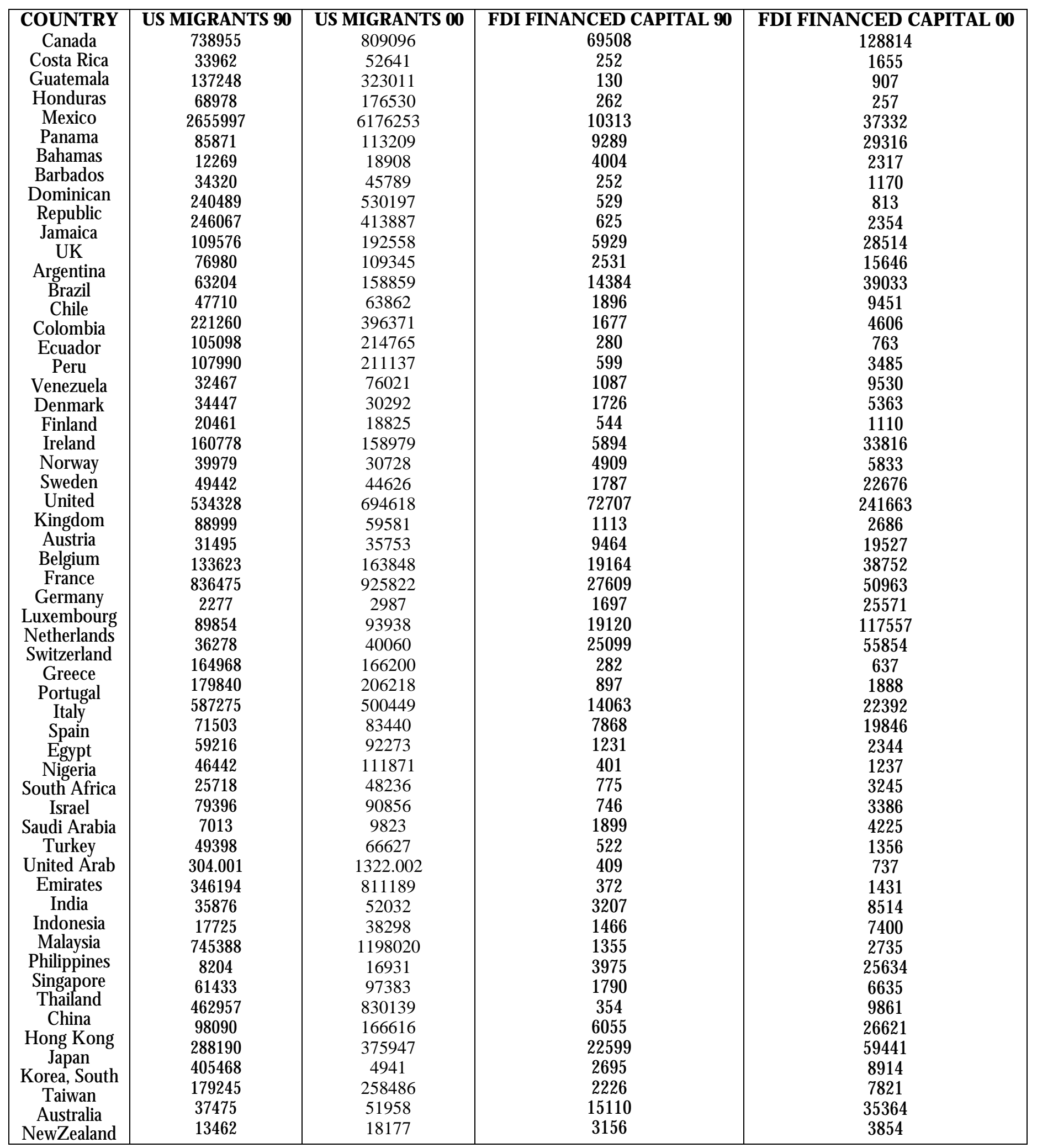

Notes: Migration stocks reported in thousands of people and capital stocks reported in millions of 1990 US dollars with " 90 " variable suffix corresponding to year 1990 levels and " 00 " suffix to year 2000 levels. 


\section{Table 2 - Summary Statistics}

Sectoral Capital Financed by FDI and Migrant Composition by Education:

\section{Stocks and flows}

\begin{tabular}{|c|c|c|c|c|}
\hline VARIABLE & MEAN & $\begin{array}{l}\text { STANDARD } \\
\text { DEVIATION }\end{array}$ & MINIMUM & MAXIMUM \\
\hline$\Delta \mathrm{K} \mathrm{TOT}$ & 1.171053 & 6742091 & -.54702 & 3.327045 \\
\hline $\mathrm{K} \mathrm{TOT}_{1990}$ & 7.722503 & 1.562444 & 1.562444 & 11.19419 \\
\hline$\Delta \mathrm{K} \mathrm{MAN}$ & 1.330517 & 2.230985 & -1.425655 & 12.62149 \\
\hline $\mathrm{K} \mathrm{MAN}_{1990}$ & 5.768116 & 3.591764 & -6.907755 & 10.41253 \\
\hline$\Delta \mathrm{K}$ SER & 3.519508 & 4.707519 & -8.006368 & 15.99219 \\
\hline $\mathrm{K} \mathrm{SER}_{1990}$ & .9125442 & 5.332361 & -6.907755 & 7.990915 \\
\hline$\Delta \mathrm{M}$ PRI & -.1950974 & .9222775 & -4.04217 & 1.53527 \\
\hline $\mathrm{M} \mathrm{PRI}_{1990}$ & 8.825225 & 2.796136 & -6.907755 & 14.25432 \\
\hline$\triangle \mathrm{M} \mathrm{SEC}$ & -.0451762 & 1.831756 & -11.2772 & 1.260745 \\
\hline $\mathrm{M} \mathrm{SEC}_{1990}$ & 10.09821 & 1.602961 & 4.369448 & 13.53907 \\
\hline$\triangle \mathrm{M} T E R$ & .4465127 & .6800715 & -4.009286 & 1.770801 \\
\hline $\mathrm{M} \mathrm{TER}_{1990}$ & 10.50365 & 1.408626 & 5.416101 & 13.13872 \\
\hline
\end{tabular}

$\mathbf{N}$ umber of observations per variable is 55 corresponding to the number of countries for which we can construct our historical stock variables of emigration by schooling level and sectoral capital formation financed with FDI, where the host country of the subsidiary is the country of origin of the migrant.

Definitions: $\Delta \mathrm{K}$ sis change in the 1990's in the log of scapital stock financed with FDI from US (where henceforth $\mathrm{s}=$ TOT, MAN and SER stands for total, manufacturing and services respectively), $\mathrm{K} \mathrm{s}_{1990}$ is the log of the historical sstock in 1990 of capital financed with FDI from the US, $\Delta \mathrm{M}$ eis the change in the 1990's of the log of the stock of migrants in the US with eeducational attainment (where henceforth $\mathrm{e}=$ PRI, SEC and TER for primary, secondary and tertiary respectively), and $\mathrm{M}_{1990}$ is the log of the stock of migrants in the US in 1990 with eeducational attainment. 


\section{Table 3 - Emigration and FDI inflows}

Dep. Var.: growth in capital financed with FD I from the US in 1990's

\begin{tabular}{|c|c|c|c|}
\hline Constant & $\begin{array}{l}1.499236 \\
(.9434182)\end{array}$ & $\begin{array}{c}1.619913 \\
(1.961791)\end{array}$ & $\begin{array}{c}18.32049 \\
(5.938741)\end{array}$ \\
\hline $\begin{array}{l}\text { GD P per capita of } \\
\text { host in } 1990 \text { (log) }\end{array}$ & $\begin{array}{l}.105372 \\
(.038974)\end{array}$ & $\begin{array}{l}.319913 \\
(.061791)\end{array}$ & $\begin{array}{l}.091347 \\
(.051791)\end{array}$ \\
\hline $\begin{array}{l}\text { GDP of host in } 1990 \\
\text { (log) }\end{array}$ & $\begin{array}{l}.199136 \\
(.079463)\end{array}$ & $\begin{array}{l}.569131 \\
(.232561)\end{array}$ & $\begin{array}{l}.013814 \\
(.006192)\end{array}$ \\
\hline $\mathrm{KTOT}_{1990}(\log )$ & $\begin{array}{c}-.070537 \\
(.0758481)\end{array}$ & -- & -- \\
\hline $\mathrm{KMAN}_{1990}(\log )$ & -- & $\begin{array}{l}-.3713256 \\
(.074652)\end{array}$ & -- \\
\hline $\mathrm{KSER}_{1990}(\log )$ & -- & -- & $0.001(0.69)$ \\
\hline $\mathrm{MPRI}_{1990}(\log )$ & $\begin{array}{l}.2162047 \\
(.0695231)\end{array}$ & $\begin{array}{l}.2096735 \\
(.3048121)\end{array}$ & $\begin{array}{l}-.3224105 \\
(1.02825)\end{array}$ \\
\hline $\operatorname{MSEC}_{1990}(\log )$ & $\begin{array}{l}-.5635226 \\
(.3495073)\end{array}$ & $\begin{array}{l}-.3314846 \\
(.683885)\end{array}$ & $\begin{array}{c}3.461478 \\
(2.331489)\end{array}$ \\
\hline $\mathrm{MTER}_{1990}(\log )$ & $\begin{array}{l}.4390899 \\
(.2437978)\end{array}$ & $\begin{array}{l}1.602782 \\
(.5472631)\end{array}$ & $\begin{array}{c}4.381484 \\
(1.805951)\end{array}$ \\
\hline$\Delta \mathrm{M}$ PRI (log diffs) & $\begin{array}{l}.1512915 \\
(.2182103)\end{array}$ & $\begin{array}{l}.8442118 \\
(.4731091)\end{array}$ & $\begin{array}{c}2081284 \\
(1.197774)\end{array}$ \\
\hline$\triangle \mathrm{M}$ SEC (log diffs) & $\begin{array}{l}-.0603085 \\
(.1366381)\end{array}$ & $\begin{array}{l}-.7071812 \\
(.2622901)\end{array}$ & $\begin{array}{l}.5721065 \\
(.9354538)\end{array}$ \\
\hline$\Delta \mathrm{M} T E \mathrm{R}$ (log diffs) & $\begin{array}{l}-.0831427 \\
(.2677519)\end{array}$ & $\begin{array}{c}2308714 \\
(.55928993)\end{array}$ & $\begin{array}{c}-3.33648 \\
(1.637666)\end{array}$ \\
\hline $\begin{array}{l}\text { Regional fixed } \\
\text { effects }\end{array}$ & YES & YES & YES \\
\hline $\begin{array}{c}\text { Regional interaction } \\
\text { effects }\end{array}$ & YES & YES & YES \\
\hline R-squared & 0.3582 & 0.5491 & 0.4976 \\
\hline No. of observations & 55 & 55 & 55 \\
\hline
\end{tabular}

(1)

(2)

(3)

\section{Total Manufacturing}

1.619913

Services

18.32049

.013814

-

